\title{
Behind the scenes: family involvement and educational achievements of second-generation Turks in Austria, France and Sweden
}

Philipp Schnell ${ }^{1,2}$

Correspondence:

philipp.schnell@univie.ac.at

${ }^{1}$ University of Vienna, Vienna

Austria

${ }^{2}$ Swiss Forum for Migration and

Population Studies, University of

Neuchatel, Neuchatel, Switzerland

\begin{abstract}
This article explores school-related involvement strategies within Turkish families in Austria, France and Sweden and their linkages with educational achievements of their children. Using data from the TIES survey, results show that the educational attainment of second-generation Turks in Austria is much more dependent on various activities of support provided by their parents when compared to their counterparts in France and Sweden after holding family background characteristics constant. Besides, the educational success of second-generation Turks in Austria is reliant on the extra support they receive from older siblings beyond parental involvement and education background. No such significant effects were observed in either France or Sweden. The paper further reveals that second-generation Turks are more reliant on educational support from their parents than are the children of majority families within Austria. The paper suggests that these different findings across countries have to be read in the light of interaction mechanisms with institutional settings of the given education systems.
\end{abstract}

Keywords: Family involvement; Children of immigrants; Second generation; Turks; Education; TIES

\section{Introduction}

The educational success of the Turkish second generation in Europe, one of the largest immigrant origin group and among the most disadvantaged in terms of education (Crul \& Vermeulen, 2003; Penn \& Lambert, 2009), depends not only on the cognitive ability, motivation, and aspirations of the children, but also to a large extent on the educational, social, and economic resources available in their families. The education level of the parents in particular is one of the most important characteristics in the family context. This finding is in line with most of the international research on immigrant youth and schooling outcomes (Heath \& Brinbaum, 2007; Zhou, 1997). However, parental socio-economic status is not all that counts. There is also a view that the most important factor in explaining the transmission of resources is the quality of ties between generations (Allmendinger, Ebner, Nikolai, Franzen \& Freitag, 2007; Horvat, Weininger \& Lareau, 2003). Young adolescents will not benefit from the help of their parents if the relationship between them is weak or if parents are not engaged in their school activities. Central to this argument is research that has shown that children of immigrants benefit from such involvement and

(C) 2015 Schnell. Open Access This article is distributed under the terms of the Creative Commons Attribution 4.0 International License (http://creativecommons.org/licenses/by/4.0/), which permits unrestricted use, distribution, and reproduction in any medium, provided you give appropriate credit to the original author(s) and the source, provide a link to the Creative Commons license, and indicate if changes were made. 
that parents are crucial in determining their children's experiences and academic success (Kao, 2004a; Turney \& Kao, 2009). Besides, recent research on intergenerational upward mobility among disadvantaged second-generation youths documents that parental involvement in children's upbringing and education might counterbalance the impact of disadvantaged origin. High parental ambitions, expectations, aspirations and specific types of parental support have been found to be the driving force for these successful achievements (Portes \& Fernandez-Kelly, 2008; Schnell, Keskiner and Crul, 2013).

Most previous research, however, stems from national studies that provide some evidence that the effectiveness of involvement for educational achievements varies across different origin groups (Kao, 1995; Pong, Hao \& Gardner, 2005; Rosenbaum \& Rochford, 2008), while studies looking systematically at parental involvement and possible variations within the same origin group across countries doesn't exit so far. But especially within Europe, where education systems vary widely, ranging from countries with full-day teaching systems with no or limited differentiation between tracks until the end of compulsory education to countries with half-day tutoring and highly differentiated tracking structures, cross-national differences in the effects of family involvement on educational outcomes for children of (Turkish) immigrants might be expected.

Moreover, I argue that most of the previous studies are too narrowly framed, investigating only parental influences. Especially in immigrant families, it is often the older siblings who act as role models and provide their younger brothers and sisters with information and support, making them as effective as parents (Crul, 2000, p.: 240; Zhou \& Bankston, 1998). Older siblings can act as intermediaries between younger children and their schools. Their own schooling experiences can also be a major source of support - a significant factor that is most often ignored within studies on school success by children of immigrants and second-generation Turks in particular.

In this paper, I aim to extend the discussion about family influences on education outcomes by investigating the role of parents and older siblings for second-generation Turks in a cross-national comparison. I explore the involvement strategies and patterns of support provided by Turkish families in three North-Western European countries, namely Austria, France and Sweden. In particular, I ask: (1) to what extent is the educational attainment of second generation Turks associated with family influence in the three compared countries? (2) Does support and involvement by (older) siblings exert any influence beyond that of parental involvement on the educational outcomes of the Turkish second generation? Do Turkish families muster more family involvement for education than majority families?

In sum, this article attempts to identify the role of educational support provided by family members for the educational success of the Turkish second generation and to ascertain variations in its relevance across educational systems with different institutional arrangements. At the same time, all three countries share the fact that the majority of the Turkish community migrated for work or family reasons and that they represent a substantial proportion of each country's (former) labour migrants. Although this study is accompanied by the classic small-number problem at country level (Coppedge, 1999; Lieberson, 1991), it allows a systematically conducted in-depth analysis of the interactions between individual-level factors, such as educational support, and national institutional arrangements. This will allow light to 
be shed on the uncertainty of various explanations that seek to clarify cross-national variations in the success of second-generation Turks at school.

In what follows, I start by briefly reviewing the main theoretical mechanisms through which family involvement might influence educational outcomes of immigrant origin youths. After having described the data for the empirical investigations, I classify the main aspects of involvement and further provide a short overview of how these aspects are measured in the empirical part of this study. The subsequent sections then examine the impact of parental involvement on education outcomes for second-generation Turks in the three compared countries. Afterwards, the discussion moves to the issue of siblings' influence on education outcomes, before the family involvement of Turkish and nonTurkish families are compared. The main findings are summarised in the conclusion.

\section{Family involvement and educational achievements}

Parents' involvement in their children's schooling is most often conceptualised as a form of social capital (McNeal, 1999; Turney \& Kao, 2009, p.: 258). Social capital is understood as a set of networks and connections in which actors secure benefits and resources by virtue of membership and contacts (Portes, 1998). Parent-child relationships are networks in which children benefit from parental involvement in their education through a number of different mechanisms (Domina, 2005; Nauck \& Kohlmann, 1998): First, parents' involvement with schools can show children that education is valued and of importance for the family, which may ultimately translate into greater appreciation of education on the part of the children themselves. Parental involvement also provides parents with means of social control through directly controlling the time their children spend on homework. Additionally, they get to know other parents and teachers with whom they discuss their children's performances. Lastly, involved parents are privy to substantially more information about their children.

Through these mechanisms, parental involvement has a lasting influence on the performance of their children at school, and most researchers have found that higher levels of parental influence leads to significant advantages (Faas, Benson \& Kaestle, 2013; Melby, Conger, Fang, Wickrama \& Conger, 2008). Parent-school involvement and inter-generational closeness have been found to be positively related to the education outcomes of children of immigrants, benefitting measures such as average grades or tests scores (Kao \& Rutherford, 2007) or preventing certain types of behaviour by the second-generation, such as truancy (McNeal, 1999).

While family involvement has been a substantial focus in social capital theory and in the sociology of education, literature on the role played by particularly older siblings in supporting younger family members is scarce. I aim to overcome this limitation by arguing that siblings' involvement in the schooling of their younger brothers and sisters can be conceptualised as an important form of family capital as well because the mechanisms are similar those of parental involvement. Older siblings can play a crucial role in the socialisation process by acting as a positive or negative role model, by promoting forms of control within the family, or by providing additional concrete support through participation (Crul, 2000; Malecki \& Demaray, 2003). Although some authors tend to argue that educational support by (older) siblings is negatively correlated with the number of siblings within a family (e.g. Guo \& VanWey (1999); for caution see Chen and Liu (2014)), recent empirical research demonstrates that descendants of immigrants are 
not as negatively affected by large family size than children from the majority population (Moguérou, Santelli, Primon, \& Hamel, 2013). As Moguérou and Santelli argue in their article in this issue, elder siblings in immigrant families frequently help realize their parents' educational aspirations and compensate for what the parents have not been able to provide, despite their ambition. This specific practise and type of support is much more common in immigrant families as compared to non-immigrant families of the same social class (Moguérou \& Santelli, 2015).

\section{Data}

Data comes from the "The Integration of the European Second-generation" (TIES) survey. TIES is a collection of data about the children of immigrants from Turkey (as well as Western Balkan and Morocco) in 15 European cities in eight western European countries, which was carried out between 2007 and 2008 (Crul, Schneider \& Lelie, 2012). The term 'second-generation' refers to children of immigrants who were born in the country of immigration. At the time of the interviews, all respondents were between 18 to 35 years old. In each city surveyed, there was a comparison group whose parents were both born in the survey country.

Out of the eight participating countries, Austria, France and Sweden have been selected for comparison. With respect to the structure of the education system, Austria (Vienna and Linz) and Sweden (Stockholm) have been selected from the pool of available countries. Sweden has a comprehensive education system with late selection and full-day teaching. In contrast, Austria can be described as a country with a noncomprehensive system, early selection and half-day teaching. Finally, France (Strasbourg and Paris) has been selected as a third case for this comparison. Although its education system is comprehensive and resembles the structure of the Swedish system, a number of national studies have revealed that France has high-stakes testing at the end of compulsory education, as well as selectivity across subjects in upper-secondary education, leading to what I call a 'selective comprehensive system' (Schnell, 2014), making France an interesting contrasting case.

Using data from the TIES survey over other sources, such as the Programme for International Student Assessment Study (PISA), has a number of advantages. Largescale assessment surveys oftentimes lack information on the country of origin of the students' parents - information which is needed in order to classify origin groups. Thus, the drawback of these studies is that they classify second-generation students of various origin groups in one 'category' across countries, which leads to imprecise analysis of the actual position of specific groups, such as second-generation Turks, across countries. Instead, the TIES survey is very useful for the purposes of this study because it is the first comparative survey across Europe that was designed to study a wide range of characteristics as well as the situation of Turkish second-generation youngsters from a comparative perspective. To be more precise, it contains standardised education outcomes, such as the highest obtained education level and the rate of early school leaving. A second advantage of this data set is the richness of family-related information. It contains further a wide range of questions related to the migration histories of Turkish fathers and mothers, their situations in the receiving countries, along with information on the structural characteristics of their families. Thirdly, several survey items have been included to capture family involvement during the education careers of the 
respondents. This information will allow the investigation of family involvement strategies and the different levels of social capital in Turkish families. The TIES survey even goes a step further than the information that is usually available on family support and involvement in other surveys by providing information on older and younger siblings and their perceived roles in supporting the respondents in school.

Taken together, the empirical analyses presented throughout this study are based the TIES survey with a total sample of 2,294 respondents. All relevant variables used for the analysis are described in the sections below. An overview table with descriptive results is given in the Table 1 .

\section{Results}

\section{Parental involvement}

Since parental involvement is a multidimensional construct (Domina, 2005; Turney \& Kao, 2009), the various aspects of parental influence need to be classified into a number of broad dimensions. The three dimensions outlined here are partially derived from James Coleman's concept of social capital (Coleman, 1988; Morgan \& Sørensen, 1999), and have been further developed and applied in studies of parental influence on the educational performance of immigrant youth (Kao, 2004b; Lauglo, 2000; Sun, 1998). The first dimension is parental control and it comprises the constructive engagement of parents with the school-related activities of their children. It includes issues such as whether parents control the time children spend doing homework, whether they know their children's friends, and whether they discuss school experiences with their children. Parental control is one important way in which parents can communicate their expectations to their children. The second dimension describes the concrete and practical involvement of parents in school-related activities. Help with homework, frequent contact with teachers and voluntary participation in school activities can be labelled parental participation (Lauglo, 2000).

In the TIES survey, which the present study utilises, two indicators are available per dimension. To begin with, parental control is captured in two survey items asking (1), 'whether parents control the time their child spends on homework' and (2), 'whether they talked with them about school or studies'. In order to measure participation, survey information on (1), whether parents helped with homework and (2), how frequently they met their children's teachers is considered. Each of the four variables had five answer categories ranging from 'never' to 'often'.

As well as these indicators that are derived from social capital literature, a fifth variable on the perceived importance of parents in supporting their child with his or her studies is included, in order to provide information on the quality of ties between generations in the educational attainment process. This variable serves as the third dimension of parental influence.

The prevalence of those dimensions for second-generation Turks in the five cities under consideration is displayed in Fig. 1. The black bars show the percentage distribution of the highest categories 'regularly' and 'often', while the black diamond represents the mean value on the five-point scale for second-generation Turks. I further generated an additional 'parental support index' which comprises the four items making up the behavioural dimension (participation and control). ${ }^{1}$ All the items presented below are treated as continuous variables ranging from low (1) to high (5) involvement. 
Table 1 Descriptive outcomes of (in-) dependent variables, by group and city

\begin{tabular}{|c|c|c|c|c|c|c|c|c|c|c|c|c|}
\hline \multirow[b]{3}{*}{ Variable } & \multirow{3}{*}{\multicolumn{2}{|c|}{ Metric }} & \multicolumn{4}{|c|}{ Austria } & \multicolumn{4}{|c|}{ France } & \multirow{2}{*}{\multicolumn{2}{|c|}{$\begin{array}{l}\text { Sweden } \\
\text { Stockholm }\end{array}$}} \\
\hline & & & \multicolumn{2}{|c|}{ Vienna } & \multicolumn{2}{|l|}{$\operatorname{Linz}$} & \multicolumn{2}{|l|}{ Paris } & \multicolumn{2}{|c|}{ Strasbourg } & & \\
\hline & & & $2 \mathrm{GT}$ & $C G$ & 2GT & $C G$ & 2GT & $C G$ & 2GT & CG & 2GT & $C G$ \\
\hline \multicolumn{13}{|l|}{ DEPENDENT VARIABLES } \\
\hline \multirow[t]{2}{*}{ Early school leavers } & \multicolumn{2}{|c|}{$1=$ Yes } & 0.29 & 0.14 & 0.19 & 0.08 & 0.09 & 0.03 & 0.19 & 0.03 & 0.09 & 0.04 \\
\hline & \multicolumn{2}{|c|}{$0=$ No } & $(0.45)$ & $(0.34)$ & $(0.39)$ & $(0.28)$ & $(0.27)$ & $(0.18)$ & $(0.39)$ & $(0.14)$ & $(0.28)$ & $(0.18)$ \\
\hline \multirow[t]{2}{*}{ High achiever } & \multicolumn{2}{|c|}{$1=$ Yes } & 0.14 & 0.35 & 0.22 & 0.33 & 57.7 & 0.70 & 0.31 & 0.71 & 47.4 & 0.62 \\
\hline & \multicolumn{2}{|c|}{$0=\mathrm{No}$} & $(0.35)$ & $(0.47)$ & $(0.42)$ & $(0.42)$ & $(0.49)$ & $(0.45)$ & $(0.46)$ & $(0.45)$ & $(0.47)$ & $(0.48)$ \\
\hline \multicolumn{13}{|l|}{ PARENTS } \\
\hline \multirow[t]{2}{*}{ Importance of parents } & $1=$ & $\begin{array}{l}\text { not } \\
\text { important }\end{array}$ & 2.76 & 3.10 & 3.16 & 3.18 & 3.26 & 3.54 & 2.65 & 3.47 & 2.07 & 2.65 \\
\hline & $5=$ & $\begin{array}{l}\text { very } \\
\text { important }\end{array}$ & $(1.1)$ & $(1.2)$ & $(1.2)$ & $(1.2)$ & (1.3) & $(1.1)$ & $(1.4)$ & $(0.9)$ & $(1.1)$ & (1.1) \\
\hline \multirow[t]{2}{*}{ Homework control } & $1=$ & never & 2.86 & 2.91 & 3.26 & 2.71 & 3.02 & 3.23 & 2.72 & 3.53 & 2.41 & 1.93 \\
\hline & $5=$ & often & $(1.2)$ & $(1.2)$ & $(1.2)$ & $(1.2)$ & $(1.3)$ & $(1.4)$ & $(1.5)$ & (1.3) & $(1.2)$ & (1.1) \\
\hline \multirow[t]{2}{*}{ Talking about school } & $1=$ & never & 3.38 & 3.27 & 3.61 & 3.52 & 3.65 & 3.93 & 3.73 & 4.05 & 3.65 & 3.54 \\
\hline & $5=$ & often & $(1.2)$ & $(1.2)$ & $(1.2)$ & $(1.1)$ & $(1.1)$ & $(1.0)$ & $(1.2)$ & $(1.0)$ & $(1.0)$ & $(0.9)$ \\
\hline \multirow{2}{*}{$\begin{array}{l}\text { Helping with } \\
\text { homework }\end{array}$} & $1=$ & never & 2.53 & 2.81 & 2.84 & 2.81 & 2.07 & 2.98 & 1.68 & 3.06 & 1.89 & 2.48 \\
\hline & $5=$ & often & $(1.2)$ & $(1.1)$ & $(1.3)$ & $(1.1)$ & $(1.2)$ & $(1.3)$ & $(1.1)$ & (1.1) & $(1.0)$ & (1.0) \\
\hline \multirow[t]{2}{*}{ Contact with teachers } & $1=$ & never & 3.30 & 2.93 & 3.33 & 2.71 & 3.00 & 3.31 & 2.96 & 3.28 & 2.38 & 2.13 \\
\hline & $5=$ & often & $(1.2)$ & (1.1) & (1.3) & (1.1) & $(1.1)$ & $(1.0)$ & $(1.3)$ & $(1.0)$ & $(1.0)$ & $(0.8)$ \\
\hline \multirow{2}{*}{$\begin{array}{l}\text { Parental support } \\
\text { index }\end{array}$} & $1=$ & never & 3.02 & 2.98 & 2.93 & 3.25 & 2.94 & 3.36 & 2.78 & 3.48 & 2.58 & 2.52 \\
\hline & $5=$ & often & $(1.0)$ & $(0.9)$ & $(0.8)$ & $(1.1)$ & $(0.9)$ & $(0.8)$ & $(1.0)$ & $(0.8)$ & $(0.8)$ & $(0.7)$ \\
\hline SIBLINGS & & & & & & & & & & & & \\
\hline Importance of siblings & $1=$ & $\begin{array}{l}\text { not } \\
\text { important }\end{array}$ & 2.32 & 1.64 & 2.83 & 1.88 & 1.80 & 2.24 & 2.38 & 2.16 & 3.01 & 3.90 \\
\hline & $5=$ & $\begin{array}{l}\text { very } \\
\text { important }\end{array}$ & $(1.5)$ & $(1.1)$ & $(1.7)$ & $(1.3)$ & $(1.2)$ & (1.4) & $(1.4)$ & $(1.5)$ & (1.4) & (1.1) \\
\hline Help with homework & $1=$ & never & 2.11 & 1.56 & 2.49 & 1.70 & 1.80 & 1.58 & 2.17 & 1.53 & 1.69 & 1.34 \\
\hline & $5=$ & often & (1.4) & $(1.0)$ & $(1.5)$ & $(1.1)$ & (1.3) & $(0.9)$ & (1.4) & $(1.0)$ & $(1.0)$ & $(0.8)$ \\
\hline Talking about school & $1=$ & never & 2.02 & 1.48 & 2.3 & 1.78 & 1.99 & 1.93 & 2.48 & 1.75 & 2.58 & 2.14 \\
\hline & $5=$ & often & (1.3) & $(0.9)$ & (1.4) & $(1.1)$ & (1.3) & $(1.2)$ & (1.6) & (1.1) & $(1.2)$ & (1.1) \\
\hline Sibling support index & $1=$ & never & 2.07 & 1.52 & 2.39 & 1.74 & 1.89 & 1.75 & 2.32 & 1.64 & 2.13 & 1.74 \\
\hline & $5=$ & often & (1.3) & $(0.9)$ & (1.4) & (1.0) & $(1.2)$ & $(1.0)$ & (1.4) & $(1.0)$ & $(0.9)$ & (0.8) \\
\hline Has older siblings & $1=$ & Yes & 0.11 & 0.03 & 0.10 & 0.03 & 0.03 & 0.08 & 0.50 & 0.07 & 0.09 & 0.07 \\
\hline & $0=$ & No & $(0.3)$ & $(0.2)$ & $(0.3)$ & $(0.2)$ & $(0.2)$ & $(0.3)$ & $(0.4)$ & $(0.3)$ & $(0.3)$ & (0.3) \\
\hline Number of older & $0-10$ & & 2.62 & 1.10 & 2.14 & 1.45 & 2.01 & 1.79 & 2.99 & 1.74 & 3.19 & 2.13 \\
\hline & & & (1.4) & $(1.2)$ & $(1.1)$ & $(1.2)$ & $(1.2)$ & $(1.4)$ & $(1.7)$ & (1.4) & (1.6) & (1.4) \\
\hline CONTROL VARIABLES & & & & & & & & & & & & \\
\hline Parents' host-country & $1=$ & Not at all & 4.01 & - & 4.55 & - & 3.82 & - & 3.62 & - & 4.89 & - \\
\hline & $6=$ & Very well & $(1.0)$ & & $(1.0)$ & & $(1.0)$ & & (1.1) & & $(0.8)$ & \\
\hline $\begin{array}{l}\text { Parents' Educational } \\
\text { level }\end{array}$ & $1=$ & $\begin{array}{l}\text { no school/ } \\
\text { primary }\end{array}$ & 2.21 & & 2.38 & & 2.22 & & 1.83 & & 2.39 & \\
\hline & $4=$ & $\begin{array}{l}\text { Post-sec./ } \\
\text { tertiary }\end{array}$ & $(1.0)$ & & (1.1) & & $(1.1)$ & & $(0.9)$ & & $(1.2)$ & \\
\hline
\end{tabular}


Table 1 Descriptive outcomes of (in-) dependent variables, by group and city (Continued)

\begin{tabular}{|c|c|c|c|c|c|c|c|c|c|c|c|c|}
\hline \multirow{2}{*}{$\begin{array}{l}\text { Length of residence } \\
\text { in host country }\end{array}$} & $14-$ & 63 & 31.74 & - & 33.35 & - & 33.16 & - & 34.03 & - & 33.97 & \\
\hline & & & (6.8) & & (6.7) & & (4.1) & & (4.0) & & (5.2) & \\
\hline \multirow[t]{2}{*}{ Family size } & $0=$ & siblings & 2.62 & & 2.14 & & 2.02 & & 3.02 & & 2.52 & \\
\hline & $10=$ & siblings & (1.4) & & (1.1) & & (1.3) & & (1.8) & & (1.9) & \\
\hline N. & & & 252 & 250 & 206 & 234 & 248 & 174 & 252 & 177 & 251 & 250 \\
\hline
\end{tabular}

Source: TIES 2007-2008

Notes: Mean values are presented, standard deviations in brackets. $2 G T=$ Second-generation Turks $C G=$ Comparison group

The findings in Fig. 1 show that the level of support provided by Turkish families for their children varies across the three countries and five cities. The great majority of secondgeneration Turks did not receive much support from their parents in school-related matters. The most frequent type of support is talking about school, while concrete help with homework remains rare among Turkish families in all countries. Considering the parental support index (right side of Fig. 1), which includes all four items to do with control and participation, a clear ranking can be seen across countries: On average, Turkish fathers and mothers in the Austrian cities supported their children frequently in their school activities. By contrast, the great majority of second-generation Turks in Sweden did not get, nor did they need, any support from their parents. The results for France are in the centre, between Austria and Sweden.

Nevertheless, it is worth noting that when considering each parental control and participation item separately, variations in the general ranking and across cities are sometimes apparent. These differences are most pronounced when it comes to controlling the time children spent on homework. This is most common among Turkish parents in Linz, followed by those in the two French cities, and then by Vienna and Stockholm.

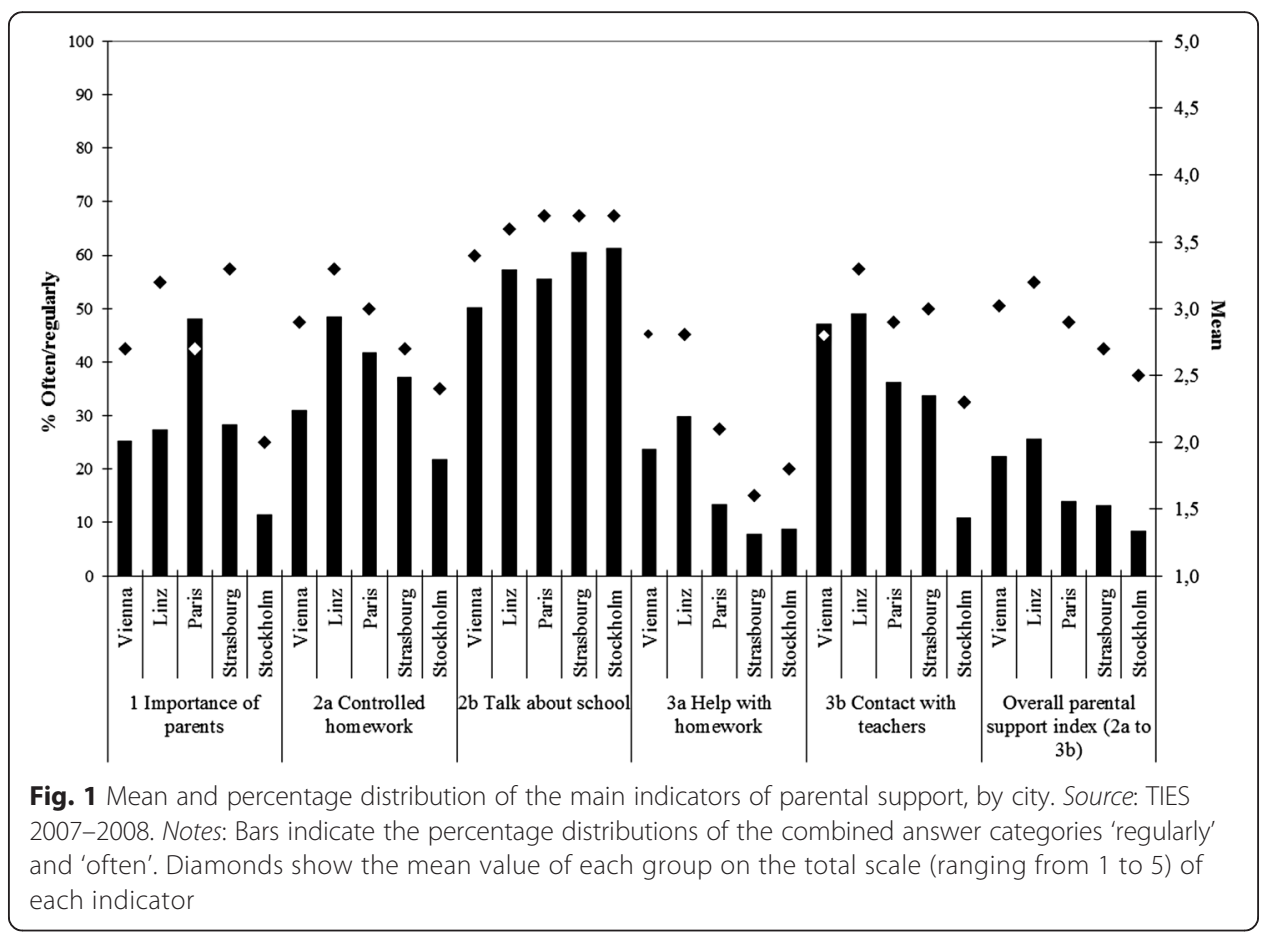


The perceived importance of parents is highest by far in Paris. Almost every second child of Turkish immigrants reported that his or her parents were important to their studies. In the Austrian cities and in Strasbourg, the equivalent proportion was around one out of four. In Stockholm, parents seemed to have little importance in supporting their children's studies. This finding is also reflected in almost all other aspects of parental support, indicating that Turkish parents in Sweden have least involvement in their children's education.

\section{Associations between parental involvement and family characteristics}

In order to understand the varying levels of parental support and engagement among Turkish families in the education-related activities of their children, correlations with the families' composition will be examined. Several studies have underlined the strong association between parental involvement and family composition and structure (Dornbusch, 1989; Dornbusch, Ritter, Leiderman, Roberts \& Fraleigh, 1987; Keefe, Padilla \& Carlos 1979). To begin with, parents' involvement in their children's schooling is shaped by the resources and opportunities that parents have. Among these resources, parents' own educational attainment and their socio-economic status have been shown to be positively associated with parents' involvement in schools. Parents who have attained more in their own education are often found to be more frequently involved in their children's schooling than parents with fewer educational qualifications (Crosnoe, 2001). In addition, family structure (e.g. family size) seems to matter. The basic assumption is derived from the resource dilution theory (Downey, 1995, 2001) that suggests that the presence of siblings may have a negative impact on parental involvement. Both aspects outlined here are highly relevant to immigrant families. There are also two immigrant-specific aspects that have been found to be positively associated with the involvement of immigrant parents: the length of time parents have spent in the receiving country, and their ability to speak the language of the receiving country (Turney \& Kao, 2009).

Table 2 shows a correlation matrix for the perceived importance of parental involvement and the parental support index along with selected family characteristics. The first results to note from Table 2 are the highly significant and positive correlations between the parental support index and parents' levels of education in the three countries and in all five cities. The higher the education levels of the parents, the more often they are able to support their children in school-related activities. However, differences in the strength of association can be seen. The estimated correlations between the parental support index is strongest in the Austrian cities, Linz and Vienna (ranging between 0.21 and 0.40 ), medium in the French cities (between 0.20 and 0.32), and lowest in Stockholm (below 0.20). Besides, a number of additional points are worth highlighting: the perceived importance of the parents is significantly associated with the parents' levels of education in the Austrian and French cities but not in Sweden. Next, negative correlations can be found between family size (Nr. of siblings) and the level of support provided by parents. When pro-scholastic resources have to be distributed among a large number of children in large families, the level of support per child seems to decline. Outliers in this respect are Turkish families in Vienna.

\section{Parental influences on the education outcomes of second-generation Turks}

In order to explore how parental influences and types of support associated with the performance of the Turkish second generation at school in the three countries I conducted 
Table 2 Correlations between the dimensions of parental support and family characteristics

\begin{tabular}{|c|c|c|c|c|c|}
\hline & $\begin{array}{c}\text { Father's } \\
\text { education } \\
\text { background }\end{array}$ & $\begin{array}{l}\text { Mother's } \\
\text { education } \\
\text { background }\end{array}$ & $\begin{array}{c}\text { Parents' } \\
\text { host-language } \\
\text { ability }\end{array}$ & $\begin{array}{l}\text { Length of residence } \\
\text { in host country }\end{array}$ & $\begin{array}{l}\text { Family } \\
\text { size }\end{array}$ \\
\hline \multicolumn{6}{|l|}{ Austria } \\
\hline \multicolumn{6}{|l|}{ Vienna } \\
\hline Importance of parents & $0.18^{*}$ & $0.16^{*}$ & $0.32^{* * *}$ & 0.05 & 0.04 \\
\hline Parental support index & $0.35^{* * *}$ & $0.21^{* * *}$ & $0.33^{* * *}$ & -0.07 & -0.04 \\
\hline \multicolumn{6}{|l|}{$\operatorname{Linz}$} \\
\hline Importance of parents & $0.30^{* * *}$ & $0.30^{* * *}$ & $0.37^{* * *}$ & -0.14 & -0.11 \\
\hline Parental support index & $0.39^{* * *}$ & $0.40^{* * *}$ & $0.45^{* * *}$ & -0.16 & $-0.17^{*}$ \\
\hline \multicolumn{6}{|l|}{ France } \\
\hline \multicolumn{6}{|l|}{ Paris } \\
\hline Importance of parents & 0.14 & $0.17^{*}$ & $0.26^{* * *}$ & 0.04 & -0.04 \\
\hline Parental support index & $0.20^{*}$ & $0.30^{* * *}$ & $0.32^{* * *}$ & -0.03 & $-0.16^{*}$ \\
\hline \multicolumn{6}{|l|}{ Strasbourg } \\
\hline Importance of parents & 0.14 & $0.20^{*}$ & $0.21^{* * *}$ & -0.05 & -0.11 \\
\hline Parental support index & $0.24^{* * *}$ & $0.32^{* * *}$ & $0.32^{* * *}$ & 0.01 & $-0.19^{*}$ \\
\hline \multicolumn{6}{|l|}{ Sweden } \\
\hline \multicolumn{6}{|l|}{ Stockholm } \\
\hline Importance of parents & 0.01 & -0.10 & -0.16 & 0.13 & 0.10 \\
\hline Parental support index & $0.19^{*}$ & $0.18^{*}$ & $0.27^{* * *}$ & -0.06 & $-0.18^{*}$ \\
\hline
\end{tabular}

Source: TIES 2007-2008

Notes: Significance level: ${ }^{*} p<0.05 ;{ }^{* * *} p<0.001$

multivariate regression analysis concentrating on early school-leavers on the one hand and on high-achievers on the other as the main dependent variables because they have been proven as comparable outcome measures albeit institutional differences in the education systems in the three countries (Crul et al., 2012). The high-achievers category comprises students who have already achieved or are currently studying at post-secondary or tertiary level, and the early school-leavers category is made up of students who stopped their education after lower-secondary school (Oecd, 2005, p. 36). There is a potential advantage to using these two education outcomes as dependent variables. All questions about family influences and support were asked in relation to the period of compulsory education when the Turkish second generation was aged between twelve and fifteen. Estimating the impact that family influences have on leaving school early (directly after compulsory education), we can explore the effects on an event occurring immediately after the time period in which parental support had taken place. Examining the role of family influences on high-achievers - the second dependent variable - allowed the exploration of their effects on long-term education outcome. Looking at entering post-secondary education (high-achievers) helps to determine whether parental involvement in children's education in the most crucial time period is linked to academic or behavioural success at a later stage in their education careers.

Table 3 reports the descriptive distributions of my dependent variables in the five cities. The proportion of high-achievers is highest in Paris and Stockholm, followed by Strasbourg and then the Austrian cities. However, in Paris and Stockholm, only around 9 per cent leave school early, while the group of early school leavers in Vienna is almost three times as high. Linz and Strasbourg share the same number of early school leavers, at around 19 per cent. 
Table 3 Early school leaving and achieving post-secondary/tertiary education, second-generation Turks and city (\%)

\begin{tabular}{|c|c|c|c|c|c|}
\hline & \multicolumn{2}{|l|}{ Austria } & \multicolumn{2}{|c|}{ France } & \multirow{2}{*}{$\frac{\text { Sweden }}{\text { Stockholm }}$} \\
\hline & Vienna & $\operatorname{Linz}$ & Paris & Strasbourg & \\
\hline Early school leaver & 29.7 & 19.4 & 9.0 & 19.0 & 9.2 \\
\hline High-achiever & 14.3 & 22.8 & 57.7 & 31.0 & 47.4 \\
\hline
\end{tabular}

Source: TIES 2007-2008

Binomial logistic regression is used in order to explore the impact that parental support has on whether second-generation Turks leave school early or become high-achievers. ${ }^{2}$ Both dependent variables are dummy variables set to 1 , where the final outcome was early school leaving or achieving a post-secondary/tertiary level of education. In total, two models of increasing complexity have been employed. The first model (M1) included the combined parents support index as well as the perceived importance of parents for schooling matters. The aim is to provide a general picture of whether parental support, measured as a combination of all separate support items, exerts any influence on education outcomes. In a second step (M2), parents levels of education and their host-country language ability was added to the analysis in order to explore whether patterns of parental support remained statistically significant, even after checking for family background characteristics. Both models are further controlled for age, gender and city (e.g. Vienna versus Linz).

Table 4 displays the results for early school leaving by second-generation Turks in the three countries. The first point to take away from these estimates is that frequent parental educational support reduces significantly the odds of being an early school leaver in Austria. When turning to the results for France and Sweden, the parental support index cannot be found to have had any significant impact. ${ }^{3}$ In other words, whether Turkish families support their children frequently or not does not significantly affect the odds of them leaving school early in Sweden and France. Further, parental support remains significant for secondgeneration Turks in Austria once we also test for parents' levels of education and their

Table 4 Binomial logistic regression of leaving school early for second-generation Turks (odds ratios)

\begin{tabular}{|c|c|c|c|c|c|c|}
\hline & \multicolumn{2}{|l|}{ Austria } & \multicolumn{2}{|c|}{ France } & \multicolumn{2}{|c|}{ Sweden } \\
\hline & M1 & M2 & M1 & M2 & M1 & M2 \\
\hline \multirow[t]{2}{*}{ Importance of parents } & 1.05 & 1.11 & 0.82 & 0.96 & 0.85 & 0.90 \\
\hline & $(0.12)$ & $(0.13)$ & $(0.09)$ & $(0.26)$ & $(0.20)$ & $(0.20)$ \\
\hline \multirow[t]{2}{*}{ Parental support index } & $0.58^{* * *}$ & $0.67^{* *}$ & 0.87 & 0.93 & 0.89 & 0.98 \\
\hline & & $(0.09)$ & $(0.14)$ & $(0.15)$ & $(0.23)$ & $(0.33)$ \\
\hline \multirow[t]{2}{*}{ Parents' education level } & & $0.63^{* * *}$ & & $0.66^{* *}$ & & $0.71^{*}$ \\
\hline & & $(0.08)$ & & $(0.11)$ & & $(0.19)$ \\
\hline \multirow[t]{2}{*}{ Parents' host-country language ability } & & 0.88 & & 1.12 & & 0.93 \\
\hline & & $(0.11)$ & & $(0.17)$ & & $(0.15)$ \\
\hline \multirow[t]{2}{*}{ Capital city } & $1.65^{*}$ & 1.54 & $0.44^{*}$ & $0.50^{*}$ & n.a. & n.a. \\
\hline & $(0.39)$ & $(0.37)$ & $(0.12)$ & $(0.14)$ & & \\
\hline R2 & 0.09 & 0.15 & 0.08 & 0.11 & 0.05 & 0.08 \\
\hline$N$ & 458 & 458 & 499 & 499 & 251 & 251 \\
\hline
\end{tabular}

Source: TIES 2007-2008

Notes: Levels of significance: ${ }^{*} p<0.05 ;{ }^{* *} p<0.01 ;{ }^{* * *} p<0.001$. n.a. $=$ Not applicable. All models are controlled for age and gender 
language ability (compare Model 2). In other words, children who had more frequent exchanges about their school activities with their parents, homework control or help with homework or contact to teachers via fathers and mothers were less likely to drop out of school after compulsory education in Austria, irrespective of the parents' levels of education or language skills. Thus, it is not only the education levels of the parents and the available resources that matter in Austria, but also the amount of time and the level of support that is provided by the parents to prevent their children from leaving Austrian schools early.

With respect to parents' education levels, the estimates in Model 2 presented in Table 4 verify the importance of the level of education of the parents as an important determinant of schooling success. At the same time, its magnitude and significance varies across countries. Second-generation Turks are most dependent on their parents' education backgrounds in Austria, followed by France and then Sweden. Controlling for parents' education levels further explains the city differences in early school-leaving among secondgeneration Turks in Vienna and Linz. ${ }^{4}$ In France, city differences remain significant even after adjusting the estimates for differences in parents' education levels and schooling involvement, with the Turkish second generation in Paris still being half as likely to leave school early as their age-mates in Strasbourg. ${ }^{5}$

Figure 2 shows, per city, the predicted probability of leaving school early along the parental support index for parents with the same levels of education (lower-secondary). In Austria, as support from their parents increases, the chances that students will leave school early declines sharply. The predicted probability of being an early school-leaver in France and Sweden is relatively small, independently of the support provided by parents, and almost detached from parental involvement.

When turning to the highest end of the education spectrum, becoming a high-achiever, the results from binomial logistic regression for children of Turkish origin show similar trends (compare Table 5). To begin with, entering a level beyond upper-secondary education seems to be unrelated to any type of parental involvement and support in Sweden. The only significant driver for being a high-achiever is clearly the education level of parents - as indicated in Model 2. In Austria, children with parents who frequently supported them with school

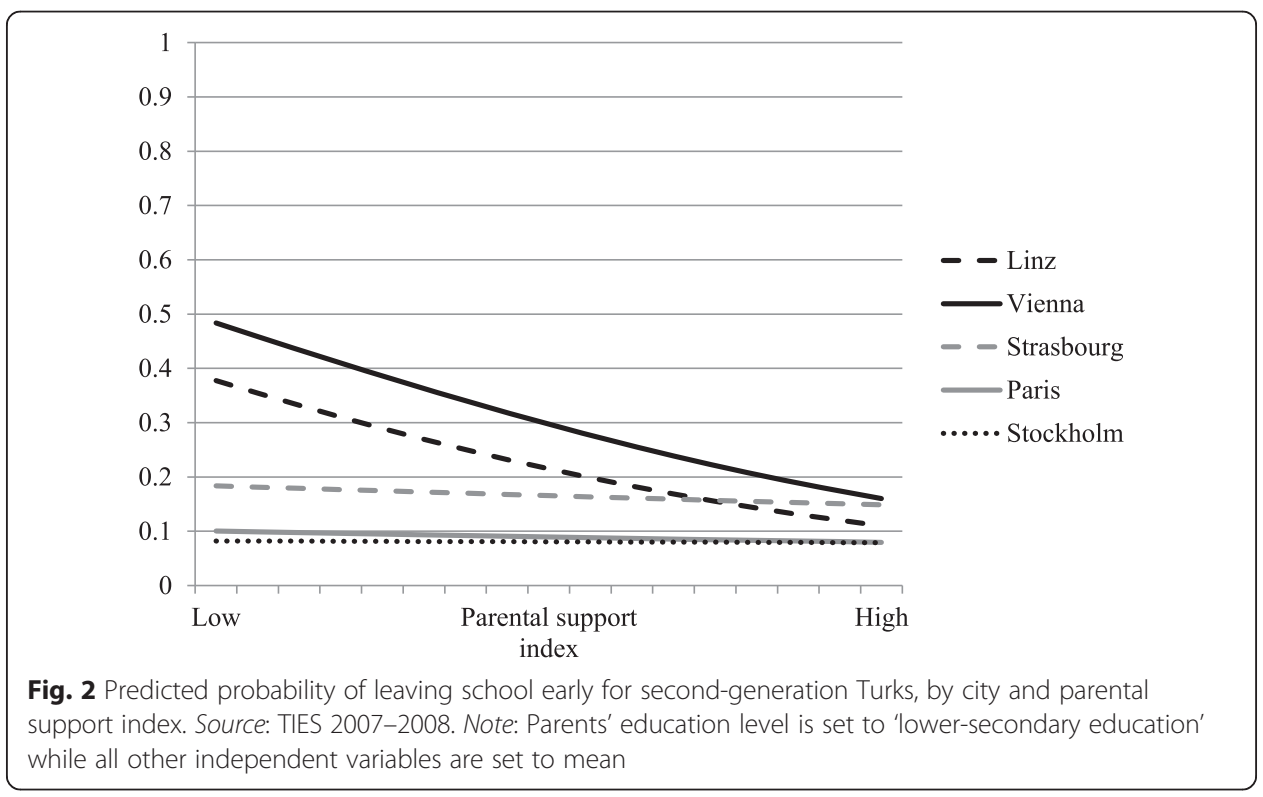


Table 5 Binomial logistic regression of achieving post-secondary/tertiary education for second-generation Turks (odds ratios)

\begin{tabular}{|c|c|c|c|c|c|c|}
\hline & \multicolumn{2}{|l|}{ Austria } & \multicolumn{2}{|l|}{ France } & \multicolumn{2}{|c|}{ Sweden } \\
\hline & M1 & $M 2$ & M1 & M2 & $\mathrm{M} 1$ & $\mathrm{M} 2$ \\
\hline \multirow[t]{2}{*}{ Importance of parents } & 0.88 & 0.87 & $1.27^{* *}$ & $1.26^{* *}$ & 1.07 & 1.06 \\
\hline & $(0.11)$ & $(0.11)$ & $(0.11)$ & $(0.10)$ & $(0.14)$ & (0.14) \\
\hline \multirow[t]{2}{*}{ Parental support index } & $1.84^{* * *}$ & $1.62^{* *}$ & 1.05 & 0.94 & 0.99 & 0.96 \\
\hline & & $(0.27)$ & $(0.12)$ & $(0.11)$ & $(0.16)$ & $(0.18)$ \\
\hline \multirow[t]{2}{*}{ Parents' education levels } & & $1.37^{*}$ & & $1.32^{* *}$ & & $1.16^{*}$ \\
\hline & & $(0.17)$ & & $(0.12)$ & & $(0.10)$ \\
\hline \multirow[t]{2}{*}{ Parents' host-country language ability } & & 0.96 & & 1.11 & & 1.00 \\
\hline & & $(0.14)$ & & $(0.12)$ & & $(0.20)$ \\
\hline \multirow[t]{2}{*}{ City (Capital) } & 0.65 & 0.68 & $2.63^{* * *}$ & $2.45^{* * *}$ & n.a. & n.a. \\
\hline & $(0.17)$ & $(0.18)$ & $(0.61)$ & $(0.49)$ & & \\
\hline R2 & 0.09 & 0.12 & 0.20 & 0.16 & 0.05 & 0.11 \\
\hline N & 458 & 458 & 499 & 499 & 251 & 251 \\
\hline
\end{tabular}

Source: TIES 2007-2008

Notes: Levels of significance: ${ }^{*} p<0.05 ;{ }^{* *} p<0.01 ;{ }^{* * *} p<0.001$. n.a. $=$ Not applicable. All models are controlled for age and gender

showed increased odds of being high-achievers. More precisely, with an increase of one unit on the 'parental support index' (for example, from 'frequently' to 'often') children's odds of entering post-secondary level almost double. So, as with the findings for leaving school early, parental support in schooling matters remains important for second-generation Turks in Austria. Model 2 in Table 5 shows further that this positive effect of parental educational support for second-generation Turks in Austria holds even after controlling for parents' education levels. In sum, the frequency of parental support to their children reveals a strong and positive association for second-generation Turks in Austria but not in France or Sweden. It is worth noting, however, that the more second-generation Turks considered their parents as important in their schooling activities, the higher became the odds of their reaching the top

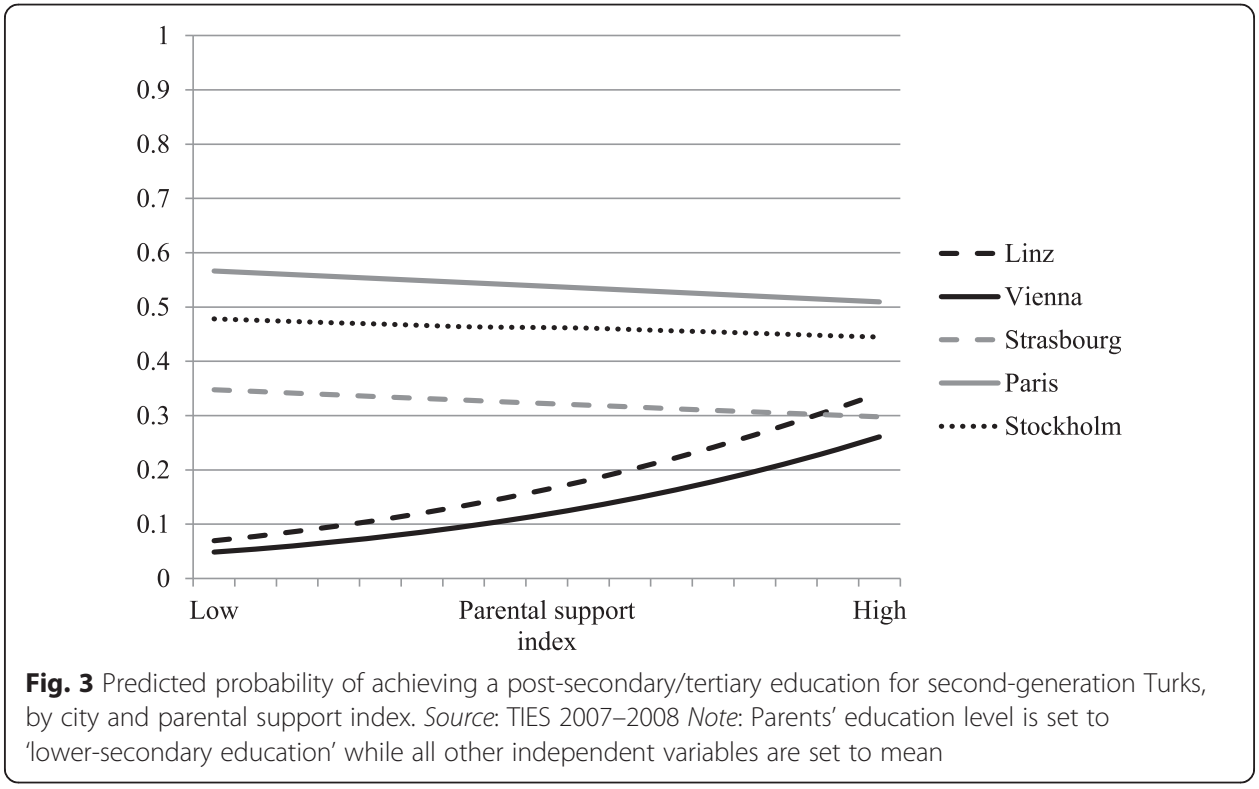


of the educational ladder in France - a finding that persists even after considering parents' levels of education and the aptitude of parents in the French language. Finally, city differences remain highly significant in favour of Paris. The odds of being a high-achiever are one-and-ahalf times higher here than in Strasbourg.

As displayed in Fig. 3, the predicted probability of second-generation Turks in Austria climbing the education ladder to the highest level without any parental support was below 10 per cent. The more support these children got at home, the sharper the increase in their chances of reaching the upper rungs of the ladder. In contrast to the trends in Austria, but similar to findings in Fig. 2, parental support does not play an extraordinary role in Paris, Strasbourg, or Stockholm.

Although not statistically significant, by displaying the predicted probability of achieving a post-secondary/tertiary level of education, a slight 'reverse effect' in terms of the effect of parental support can be seen in France and Sweden. Second-generation Turks in the French cities and in Stockholm have a reduced probability of achieving the highest levels of education when there are increased levels of parental support. The results displayed in Fig. 3 indicate that in the French and Swedish education systems, Turkish parents provide support when their child is not performing well at school.

\section{Older siblings' involvement}

The empirical dimensions of 'sibling involvement' used in this section, including measures of sibling control and participation, are similar to those used for parental involvement. In addition, a third measure is added, the perceived importance of siblings. All three measures are five-point scales ranging from low (1) to high (5). The descriptive outcomes of these three dimensions are displayed in Fig. $4 .^{6}$ The degree to which siblings are perceived as being of importance in supporting the Turkish second generation with their studies reveals that they have been evaluated as important persons for second-generation Turks in the Austrian cities,

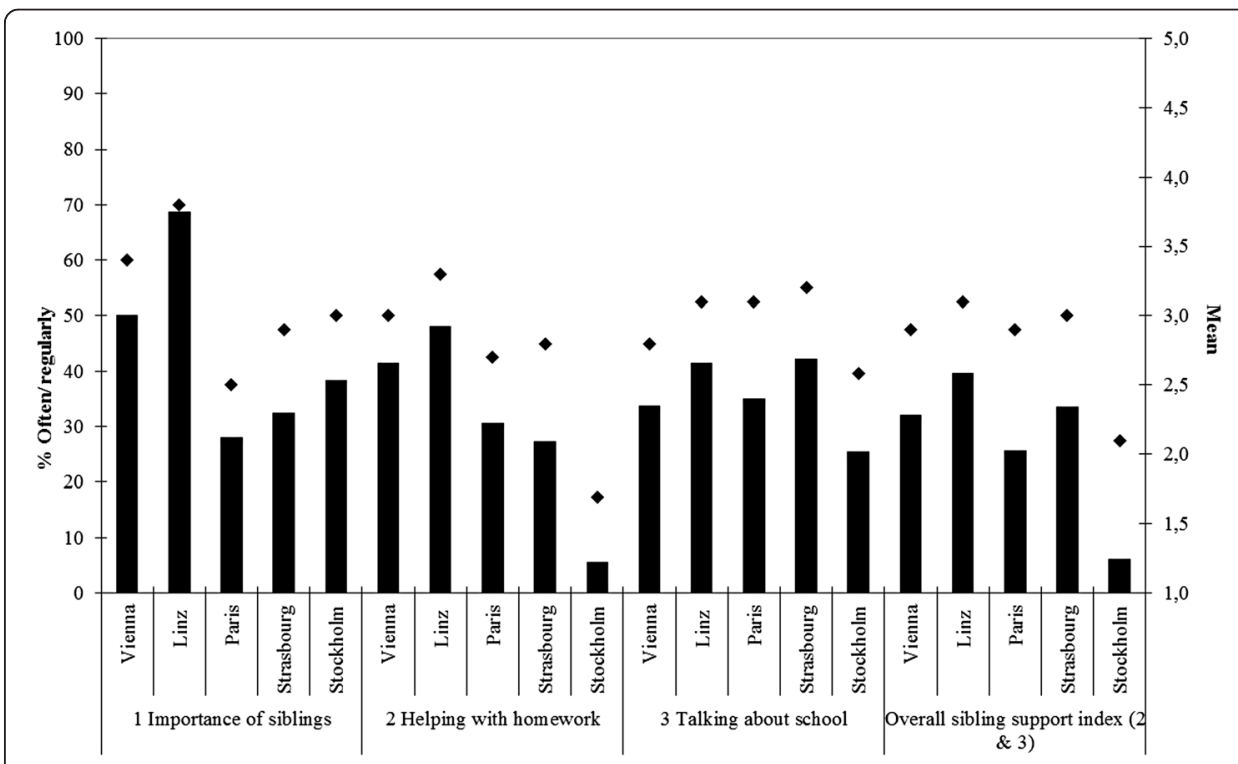

Fig. 4 Mean and percentage distribution of the main indicators of sibling support, by city. Source: TIES 2007-2008. Note: Bars indicate the percentage distributions of the combined answer categories 'regularly' and 'often'. Diamonds show the mean value of each group on the total scale (ranging from 1 to 5) of each indicator 
followed by Stockholm and the French cities (left side of Fig. 4). Turning to participation, measured as the frequency with which siblings helped with homework, we again find this pattern in the two Austrian cities more often than in France or Sweden. It is worth noting that second-generation Turks in Stockholm were only very infrequently supported in their homework by their older siblings. Similar to the outcomes for parental involvement, talking about schooling as a form of family control is the most common type of support. But on average, the ranking of cities and countries according to the frequency with which parents and children talk about school remains, as does the ranking which measures the frequency of help with homework. Interestingly, the results for older siblings' control and participation resemble the findings and rankings for the same parental indicators.

In his qualitative investigations into the importance of older siblings in terms of the school results achieved by children of immigrants in the Netherlands, Crul $(1999,2000)$ has shown that it is often the older siblings who provide their younger brothers and sisters with relevant information on and support in school activities, especially when parents do not possess the means to support their children in their studies. The findings of the correlation matrix in Table 6 partially support this argument for second-generation Turks in France and Sweden. Here, the more parents are involved in their children's school activities, the less important are their older siblings. At the same time, the concrete involvement of older siblings is not related to parental support. The strongest polarisation between countries can be seen when we consider the strength and direction of the correlation between parents' and older siblings' involvement in Austria, where the results are the diametric opposite. They show that the more parents are involved, the higher the engagement and support provided by the older siblings as well.

Table 6 Correlations between the dimensions of sibling support and family characteristics

\begin{tabular}{lll}
\hline & Family size & Parental support index \\
\hline Austria & & \\
Vienna & $0.31^{* * *}$ & $0.13^{*}$ \\
Importance of siblings & $0.27^{* * *}$ & $0.21^{* * *}$ \\
Sibling support index & & \\
Linz & $0.21^{*}$ & $0.20^{* * *}$ \\
Importance of siblings & $0.21^{*}$ & $0.26^{* * *}$ \\
Sibling support index & & \\
France & & $-0.23^{* * *}$ \\
Paris & $0.15^{*}$ & 0.06 \\
Importance of siblings & $0.25^{*}$ & \\
Sibling support index & & $-0.28^{* * *}$ \\
Strasbourg & $0.12^{*}$ & 0.07 \\
Importance of siblings & $0.17^{*}$ & \\
Sibling support index & & $0.13^{*}$ \\
Sweden & & 0.06 \\
Stockholm & 0.06 & \\
Importance of siblings & $0,18^{*}$ & \\
Sibling support index & & \\
\hline
\end{tabular}

Source: TIES 2007-2008

Notes: Levels of significance: ${ }^{*} p<0.05 ;{ }^{* *} p<0.001$ 
Table 6 shows that in all countries, the amount of support provided by older siblings increases with family size. Downey (1995) stated that the presence of siblings may be negatively related to parental involvement, and this has been proved in Table 2 as well. But the results presented here indicate that there seems to be a shift of responsibility towards older siblings when there is an increase in family size (see Table 6). At the same time, the larger the family size, the higher the likelihood of having older siblings who can provide school support.

\section{Older siblings' involvement and educational achievements}

How is the support of older siblings related to early school-leaving and high achievement? Does older siblings' involvement in school-related activities exert any influence beyond that of parental involvement on the education outcomes of the Turkish secondgeneration? In order to answer these questions, I estimated additional binomial logistic regression on both early school leaving and the likelihood of achieving post-secondary level and proceeded with a similar methodological approach to the one I used for parental involvement. All models were controlled for parents' education level, parental support, language ability, gender, capital city as well as for the total number of older siblings and whether those older siblings left school without a diploma. This was done in order explore whether there are significant effects from sibling involvement, and whether those effects are related to the number of siblings and/or to their levels of education. ${ }^{7}$

Overall, the results of the regression estimates indicate similar patterns to those of parental involvement. In Austria, increased support from older siblings significantly reduces the odds of being an early school leaver beyond the effects of parental support or parents' education levels (odds ratio: 0.66, $p<0.05$ ) and increases the chance of becoming a high-achiever (odds ratio: $1.68, p<0.01$ ), holding all other variables constant. In other words, the success in education of second-generation Turks in the Austrian education system is significantly dependent on the education levels of their parents, and the degree of involvement and support by parents and older siblings. By contrast, and in line with the findings on parental involvement, my additional results revealed that older siblings' support is not significantly associated with the two dependent variables in France and Sweden (results available upon request).

\section{Do Turkish families muster more family support for education?}

The discussion now moves on to the question of whether Turkish parents engage more or less in the school-related activities of their children than parents of the comparison group. Many studies have shown that because of their need to build new lives in their receiving countries, immigrant families frequently see education as an investment in their children as individuals, as well as in the entire family (Portes \& Fernandez-Kelly, 2008; Suárez Orozco, 1991). Immigrant parents often possess high levels of educational aspiration and have high expectations of their children. These, in turn, may translate into higher levels of parental support, which effectively transmit their ambitions to their children (Brinbaum \& Cebolla-Boado, 2007; Kao, 2004a; Zhou \& Bankston, 1998). At the same time, immigrant parents may want to be engaged in their children's school activities but may be limited in their ability to do so because of challenges such as lack of information. This section asks whether more involvement and more frequent parental support lead to greater chances of educational success for second-generation Turks compared to the comparison group. 
Table 7 takes a first look at this question by summarizing the descriptive outcomes among second-generation Turks and the comparison group. The first two columns show the mean results for each group, per city, for the full sample of the TIES survey. The lower part of Table 7 tests whether differences in the involvement of parents and older siblings can be attributed to differences in parents' education levels, by displaying the results for respondents of similar education backgrounds. Overall, the mean level of parental support is relatively equal among families in all three countries - with some minor variations across cities. Means, in terms of the parental support scale, range between 2.5 (sometimes) and 3 (regularly).

Parental support is less common in families with lower levels of education (presented at the bottom of Table 7). The average support drops for parents of the comparison group as well as for Turkish parents once we hold the parents' education levels constant in all cities. Most importantly, once the results are adjusted for differences in the education backgrounds of parents, the significant city variations in parental support disappear. The only significant difference remains among parents in Strasbourg, with Turkish parents providing significantly less support than parents of the comparison group. In all other cities, parental support does not vary among less-educated parents.

Once we turn to the involvement of siblings, clear group differences emerge. On average, second-generation Turks receive more support from their older siblings then the comparison group (with the exception of families in Paris). The lower incidence of support patterns in the families of the comparison group seem to be related to the education levels of the parents. Once we compare older siblings' involvement and support in the school activities of second-generation Turks whose parents have low levels of education, significant differences disappear in all five survey cities. Moreover, the average frequency of the support provided increases in families with less-educated parents. Older brothers and sisters become important for younger students, irrespective of their migrant background, when their parents do not possess high levels of education and when they lack the resources or the information to support their children.

Table 8 shows the results of a binomial logistic regression of achieving a postsecondary/tertiary education level. I focus on 'high achievers' only since the number of early school leavers among the comparison group in France and Sweden is too small to conduct a meaningful analysis (see Table 1). My first model includes parental support and older sibling support indices, looks at the perceived importance of the family

Table 7 The extent of parental and sibling support during compulsory school, by group and city

\begin{tabular}{|c|c|c|c|c|c|c|c|c|c|c|}
\hline & \multicolumn{5}{|c|}{ Austria } & \multicolumn{3}{|l|}{ France } & \multirow{2}{*}{\multicolumn{2}{|c|}{$\frac{\text { Sweden }}{\text { Stockholm }}$}} \\
\hline & \multicolumn{2}{|c|}{ Vienna } & \multicolumn{2}{|l|}{$\operatorname{Linz}$} & \multicolumn{2}{|l|}{ Paris } & \multicolumn{2}{|c|}{ Strasbourg } & & \\
\hline & $2 \mathrm{GT}$ & $C G$ & $2 \mathrm{GT}$ & $C G$ & $2 \mathrm{GT}$ & $C G$ & $2 \mathrm{GT}$ & CG & $2 \mathrm{GT}$ & CG \\
\hline \multicolumn{11}{|c|}{ Full sample } \\
\hline PSI & 3.0 & 2.9 & 3.2 & $2.9^{* *}$ & 2.9 & $3.3^{* * *}$ & 2.8 & $3.4^{* * *}$ & 2.5 & 2.5 \\
\hline SSI & 2.1 & $1.5^{* * *}$ & 2.4 & $1.7^{* * *}$ & 1.9 & 1.7 & 2.3 & $1.6^{* * *}$ & 2.1 & $1.7^{* * *}$ \\
\hline \multicolumn{11}{|c|}{ Only parents with lower-secondary education or below } \\
\hline PSI & 2.8 & 2.9 & 2.8 & 2.5 & 2.8 & 3.0 & 2.6 & $3.2^{*}$ & 2.4 & 2.3 \\
\hline SSI & 2.1 & 1.9 & 2.3 & 2.0 & 1.9 & 1.8 & 2.4 & 2.0 & 2.4 & 2.2 \\
\hline
\end{tabular}

Source: TIES 2007-2008

Notes: $\mathrm{PSI}=$ Parental support index. SSI = Sibling support index. Levels of significance (t-test, two-sided): group means are statistically significant on ${ }^{*} p<0.05$ level; ${ }^{* *} p<0.01$ level; ${ }^{* * *} p<0.001$ level. $2 G T=$ Second-generation Turks. $C G=$ Comparison group 
Table 8 Binomial logistic regression of achieving post-secondary/tertiary education (odds ratios)

\begin{tabular}{|c|c|c|c|c|c|c|}
\hline & \multicolumn{2}{|l|}{ Austria } & \multicolumn{2}{|l|}{ France } & \multicolumn{2}{|c|}{ Sweden } \\
\hline & $\mathrm{M1}$ & M2 & $\mathrm{M1}$ & M2 & M1 & M2 \\
\hline \multirow[t]{2}{*}{ Second-generation Turks } & $0.68^{*}$ & $0.16^{* *}$ & 0.75 & 0.65 & 0.63 & 0.76 \\
\hline & $(0.13)$ & $(0.10)$ & $(0.15)$ & $(0.46)$ & $(0.16)$ & $(0.26)$ \\
\hline \multirow[t]{2}{*}{ Importance parents } & 0.88 & 0.91 & $1.26^{* *}$ & 1.13 & 0.80 & 0.68 \\
\hline & $(0.07)$ & $(0.10)$ & $(0.09)$ & $(0.15)$ & $(0.08)$ & $(0.11)$ \\
\hline \multirow[t]{2}{*}{ Parental support index } & $1.70^{*}$ & $1.56^{*}$ & 0.98 & 1.11 & 1.03 & 1.17 \\
\hline & $(0.10)$ & $(0.13)$ & $(0.09)$ & $(0.18)$ & $(0.16)$ & $(0.30)$ \\
\hline \multirow[t]{2}{*}{ Importance of siblings } & 0.96 & 0.91 & 0.99 & 1.00 & 1.13 & 1.09 \\
\hline & $(0.09)$ & $(0.10)$ & $(0.05)$ & $(0.05)$ & $(0.14)$ & $(0.14)$ \\
\hline \multirow[t]{2}{*}{ Older sibling support index } & 1.14 & 1.02 & 0.98 & 0.88 & 1.10 & 1.08 \\
\hline & $(0.13)$ & $(0.14)$ & $(0.06)$ & $(0.11)$ & $(0.28)$ & $(0.30)$ \\
\hline \multirow[t]{2}{*}{ Parent's education level } & $1.80^{* * *}$ & $1.74^{* * *}$ & $1.62^{* * *}$ & $1.62^{* *}$ & $1.23^{*}$ & $1.18^{*}$ \\
\hline & $(0.14)$ & $(0.13)$ & $(0.12)$ & & $(0.09)$ & $(0.09)$ \\
\hline \multirow[t]{2}{*}{ Capital city } & 0.92 & 0.93 & $1.67^{* * *}$ & $1.69^{* *}$ & n.a. & n.a. \\
\hline & $(0.14)$ & $(0.15)$ & $(0.26)$ & $(0.26)$ & & \\
\hline \multirow[t]{2}{*}{ Parental support X second-generation Turks } & & $1.41^{*}$ & & 0.83 & & 0.80 \\
\hline & & $(0.22)$ & & $(0.17)$ & & $(0.26)$ \\
\hline \multirow[t]{2}{*}{ Sibling support $X$ second-generation Turks } & & $1.26^{*}$ & & 1.14 & & 0.83 \\
\hline & & $(0.17)$ & & $(0.16)$ & & $(0.22)$ \\
\hline R2 & 0.17 & 0.17 & 0.22 & 0.22 & 0.16 & 0.16 \\
\hline N. & 929 & 929 & 847 & 847 & 475 & 475 \\
\hline
\end{tabular}

Source: TIES 2007-2008

Notes: Levels of significance: ${ }^{*} p<0.05 ;{ }^{* *} p<0.01 ;{ }^{* * *} p<0.001$. n.a. $=$ not applicable. All models are controlled for age and gender. Capital city refers to Vienna in Austria and Paris in France

members in question, and has the parents' education levels as a control variable in addition to age, gender and city of residence (M1). Results for Austria indicate that more frequent parental involvement and support significantly increases the odds of becoming a high-achiever. The more parents are able to participate in and control the school activities of their children, for example, the higher the children's chances of being successful in the Austrian education system. This finding holds constant regardless of the results of testing for the education levels of the parents.

The findings also reveal that second-generation Turks in Austria remain significantly less likely to achieve a post-secondary/tertiary level of education, even after statistically controlling for family involvement and parents' levels of education. This is not the case in France, where group differences are not significant once we test for the parents' education backgrounds and for family involvement. But the chances of achieving a post-secondary/tertiary education level increase in line with greater frequency of perceived importance of the role of parents in school activities (compare Model 1). Turning finally to the findings for Stockholm, none of the measures for family involvement have a significant effect on being a high-achiever. The only significant influence is parents' levels of education. The higher parents' levels of education, the greater the chances of their children climbing to the top of the education ladder. Comparing the size of this indicator across countries, however, shows that students are least dependent on the education backgrounds of their parents in Sweden and most dependent in Austria. 
But do these identified patterns differ between second-generation Turks and their comparison groups? I test for differential effects through interactions between the parental and older siblings' support index and second-generation Turks (compare Model 2, Table 7). A significant and positive result indicates that the variable under consideration is of greater importance for second-generation Turks than for the comparison group. Figures show that no significant differential effects for second-generation Turks in France or Sweden can be observed. Thus, the insignificant role played by parental and older sibling involvement in children becoming high-achievers previously observed applies equally to both groups and therefore to the whole student population in France and Sweden.

Contrary to what holds true for France and Sweden, the effects of the involvement of the Turkish second generation's parents and older siblings are significant and positive in Austria, indicating that both types of involvement are of greater importance for second-generation Turks than for the comparison group. For example, parental support and involvement seems to be positively related to educational success for students in the Austrian education system (Model 1). But second-generation Turks seem even more dependent on the frequency of support and involvement provided by their parents. Interestingly, while the overall model presented in Model 1 did not indicate that older siblings' involvement had a significant impact, the terms of the interaction made it clear that support provided by older brothers and sisters is important for educational success for second-generation Turks in Austria. As a robustness check, I ran additional analyses in which I re-estimated Model 2 by inserting two additional interaction terms between parental and siblings support with parental educational level in order to investigate whether the observed specific importance of educational support for secondgeneration Turks persists against controls for social class effects. These additional analyses yielded non-significant results for these additional variables in all three countries while the interaction terms between educational support and second-generation Turks remained significant. ${ }^{8}$ Thus, these robustness checks reinforced my substantive conclusions, in particular for the Austrian case.

\section{Discussion and conclusion}

This study has explored patterns of family involvement in the school-related activities of Turkish families in Austria, Sweden and France. It has further examined how these involvement patterns are related to family composition, and how different types of support are linked to the education outcomes of second-generation Turks across different countries. Additionally, it has focused not only on the role played by parents, but has broadened that perspective by including the involvement of older siblings as a form of family social capital.

A number of key findings have emerged. Firstly, the frequency of parental involvement by Turkish parents varies from country to country. On average, it is most frequent in Austria, followed by France, and least frequent in Sweden. At the same time, parental involvement is most dependent on certain compositional family factors in Austria. For example, the higher the levels of education of the parents, or the better their language skills in German, the more frequently they support their children in their schooling. Although some of these factors significantly influence parental involvement in Sweden and France as well, the magnitudes were greatest in the Austrian cities. 
These patterns apply to young men and women in the same way as I could not observe any gender differences.

When turning to the relationship between education outcomes and parental involvement, a similar ranking can be observed across countries. The educational success of second-generation Turks in Austria is much more dependent on various forms of support provided by their parents when compared to their counterparts in France and Sweden. This finding remains significant even after controlling for parents' education backgrounds. In sharp contrast to these findings, parental support does not play a significant role in the educational attainment of second-generation Turks in Sweden, either in terms of not leaving school early or in terms of becoming a high-achiever. ${ }^{9}$

Examining the role of older siblings' involvement in the school activities of their younger brothers and sisters, it emerged that in Sweden and France the importance of older siblings for second-generation Turks increased when parental support was scarce. These results are in line with the findings of Crul (2000a, b) for immigrant families in the Netherlands. Older siblings seem to become a source of support when their parents are less involved in schooling. In contrast with France and Sweden, findings for Austria indicate high and positive correlations between parental and sibling involvement. Most importantly, the educational success of second-generation Turks in Austria is dependent on the extra support they receive from older siblings - beyond parental involvement and education background. No such significant effects were observed for sibling support in either France or Sweden.

Taken together, the results show that the educational success of second-generation Turks in Austria is highly dependent on the support provided by the family. At the same time, only those Turkish fathers and mothers who are equipped with higher educational credentials and advanced skills in the German language are able to support their children - and that is still a minority in the Turkish community (Schnell, 2014).

But the results of the last section revealed that the 'pressure on the family' to support their children is not per se a characteristic of Turkish families but rather a specific aspect that I relate to the structure of the Austrian education system. When looked at in relation to the comparison group, it was revealed that family involvement and support is an important aspect in Austria for all groups, while it is almost absent in France and Sweden. At the same time, results show that second-generation Turks are still more reliant on educational support from their parents than are the children of the comparison group.

The findings of this study point towards one major structural variation in those systems: as explained at the outset of this paper, one major distinction between the three education systems is the half-day school system in Austria on the one hand, and fulltime education in France and Sweden. Keeping this institutional difference in mind helps us to understand the extraordinary importance of family support for the school careers of young adolescents in Austria, as well as its relative non-significance in France and Sweden. The family becomes the main focal point of an education system which delegates learning and homework to the family home. In this context, the success of students is highly dependent on the actual help provided, and the time families spend with their children or brothers and sisters. By contrast, in the case of systems like those in France and Sweden, which offer full-time education and supervised homework tutorials in schools, the role of additional help provided by parents at home 
becomes important once their children face difficulties and need extra help in addition to the support on offer in schools.

\section{Endnotes}

${ }^{1}$ Information was combined in the index as a continuous scale capturing parental support while being at secondary school. This scale had a reliability of $\alpha>0.7$ for all groups in all cities.

${ }^{2}$ As noted by King and Zeng (2001a, 2001b), having a low rate of $Y=1$ (as in the Stockholm case), along with a small sample size, can skew the coefficients estimated using the binomial logistic regression. Therefore, I tested corrections of potential biases using the 'rare events logistic regression' model (ReLogit by King \& Zeng (2001a, 2001b)). However, running the models with 'ReLogit' changed only slightly the coefficients that were obtained (only at the $3^{\text {rd }}$ decimal).Thus, I decided to not use ReLogit given the rather small differences in the outcomes and the constraints imposed by this procedure on calculating predicted probabilities.

${ }^{3}$ I also estimated a model that comprised a squared term of the variable 'parental support index'. Previous research found that parents who exerted too much control over their children and participated in their schooling too much tended to have children with lower levels of achievement (Kao, 2004a). Note that this squared term was not statistically significant in any of my analysis. Moreover, in additional analyses, I transformed the parental support index into a categorical variable to be inserted into the model instead of the ordinally scaled measure yielding to substantially similar results.

${ }^{4}$ Comparing odds ratios across countries and regression models has very recently been criticised due to problems that stem from 'unobservables' (Karlson, Holm \& Breen, 2012; Mood, 2010). The estimates of logistic regression models are affected by omitted variables that can vary across samples, even when estimating models with the same independent variables. According to Mood (2010), average marginal and average partial effects should be used as measures for comparison instead of odds ratios. But these estimates are population averages and are not sufficient for my analysis because I am rather interested in the change in a probability that occurs for individuals on foot of a change in the independent variable. According to Mood, this can only be done by using marginal effects. But, as she notes herself, 'these measures are affected by unobserved heterogeneity, and cannot be straightforwardly compared' (Mood, 2010, p. 78). Thus, potential problems of comparability across countries remains unsolved as with the measures of odds ratios.

${ }^{5}$ Additionally, interaction terms between all indicators of parental support and the capital city (Vienna/Paris) have been included in a separate model (not shown). None of the interaction terms was statistically significant, indicating that the results here are similar for second-generation Turks in each survey city. Moreover, this finding validates the modelling strategy of combining both cities in Austria and France into one model.

${ }^{6}$ The descriptive analysis is limited to respondents with older siblings.

${ }^{7}$ Respondents without older siblings were now set to 'no support'. I re-estimated all regression models for those having older siblings only obtaining very similar results. In order to avoid small case numbers those without older siblings were included in the analysis as described before. 
${ }^{8}$ After controlling for parental and siblings support*parental educational level in Austria in Model 2 (both not significant), the odds for the interaction terms between parental and siblings support*second-generation Turks were 1.39 and 1.20, respectively (both $p<0.05$ ).

${ }^{9}$ Additional models were estimated including other controls for compositional differences within the Turkish parental generation across countries (e.g. reasons for migration (work vs. asylum) or belonging to a certain ethnic group (Kurds vs. other)). My results proved to be highly robust against these additional controls (results available upon request).

\section{Competing interests}

The author declares that he has no competing interests.

\section{Authors' contributions}

PS carried out the comparative analysis and is the sole author of this article.

\section{Authors' information}

Philipp Schnell holds a PhD in sociology from the University of Amsterdam, the Netherlands, and is a lecturer at the University of Vienna, Austria, and an affiliated researcher at the Swiss Forum for Migration and Population Studies, Neuchatel, Switzerland. His research interests include social mobility by children of immigrants in Europe, educational inequalities, neighborhoods and urban inequality in comparative perspective. Recent publications include 'Educational mobility of second-generation Turks. Cross-national perspectives' (Amsterdam: Amsterdam University Press - IMISCOE Research Series)' and 'Getting ahead. Educational and occupational trajectories of the 'new' second-generation in Switzerland' (Journal of International Migration and Integration 2015, with R. Fibbi).

Rosita Fibbi is a senior researcher and project manager at the Swiss Forum for Migration and Population Studies of the University of Neuchâtel and a Lecturer at the University of Lausanne. Her main research topics are: school and labour market integration of second generation, discrimination on the labour market for second generation youth, intergenerational relationships and elderly migrants. Among her latest publications are the co-edited volume "The New Second Generation in Switzerland. Youth of Turkish and Former Yugoslav Decent in Zürich and Basel" (Amsterdam University Press, 2015) and "Getting ahead. Educational and occupational trajectories of the 'new' second-generation in Switzerland" (Journal of International Migration and Integration 2015, with P. Schnell). Maurice Crul is a Professor of Sociology at the Free University in Amsterdam and the Erasmus University in Rotterdam. Maurice Crul mostly worked on the topic of children of immigrants in the Dutch and in a comparative European and Transatlantic context. He initiated and coordinated the international TIES project as well as the ELITES project. He is further the chair of the international IMISCOE network. His latest publications include "Super-diversity vs. assimilation: how complex diversity in majority-minority cities challenges the assumptions of assimilation" (Journal of Ethnic and Migration Studies, 2015) and "Is Education the Pathway to Success? A Comparison of Second Generation Turkish Professionals in Sweden, France, Germany and The Netherlands" (European Journal of Education, 2015).

Martha Montero-Sieburth is currently a Research Fellow at the Institute for Migration and Ethnic Studies, Department of Sociology and Anthropology, a Lecturer at the Graduate School for Social Sciences and the Social Science Research Master at University of Amsterdam, as well as Professor Emerita of the Department of Leadership in Education, Graduate College of Education, University of Massachusetts-Boston. Her most recent publication is "From intercultural education to citizenship education in the Netherlands: enhancement of cultural values or development of critical democratic citizenship?" (2015, with H. Alhadi, in: M. Catarci \& M. Fiorucci (Eds.), Intercultural education in the European context: theories, experiences, challenges. Farnham: Ashgate).

Received: 29 April 2014 Accepted: 16 April 2015

Published online: 02 October 2015

References

Allmendinger, J, Ebner, C, Nikolai, R, Franzen, A, \& Freitag, M. (2007). Soziale Beziehungen und Bildungserwerb. In Sozialkapital. Grundlagen und Anwendungen. Kölner Zeitschrift für Soziologie. Sonderheft 47 (47th ed., pp. 487-513). Wiesbaden: VS Verlag für Sozialwissenschaften.

Brinbaum, Y, \& Cebolla-Boado, H. (2007). The school careers of ethnic minority youth in France. Success or disillusion? Ethnicities, 7(3), 445-474.

Chen, Z-y, \& Liu, RX. (2014). Comparing Adolescent Only Children with Those Who Have Siblings on Academic Related Outcomes and Psychosocial Adjustment. Child Development Research, 2014(doi.org/10.1155/2014/578289).

Coleman, JS. (1988). Social capital in the creation of human capital. American Journal of Sociology, 94, 95-121.

Coppedge, M. (1999). Thickening Thin Concepts and Theories: Combining Large N and Small in Comparative Politics. Comparative Politics, 31, 465-476.

Crosnoe, R. (2001). Academic orientation and parental involvement in education during high school. Sociology of Education, 74(3),210-230.

Crul, M. (1999). Turkish and Moroccan sibling support and school achievement levels: an optimistic view. Netherlands Journal of Social Sciences, 3(2), 110-127.

Crul, M. (2000). Breaking the circle of disadvantage. Social mobility of second-generation Moroccans and Turks in the Netherlands. In H Vermeulen \& J Perlmann (Eds.), Immigrants, Schooling and Social Mobility. Does Culture Make a Difference? (pp. 225-244). London/New York: MacMillan/St.Martin's Press. 
Crul, M, Schneider, J, \& Lelie, F. (2012). The European Second Generation Compared: Does the Integration Context Matter? Amsterdam: Amsterdam University Press.

Crul, M, Schnell, P, Herzog-Punzenberger, B, Wilmes, M, Slootman, M, \& Aparicio-Gomez, R. (2012). School careers of second-generation youth in Europe. Which education systems provide the best chances for success? In M Crul, Schneider, \& F Lelie (Eds.), The European Second Generation compared: Does the integration context matter? (pp. 101-164). Amsterdam: Amsterdam University Press.

Crul, M, \& Vermeulen, H. (2003). The Second Generation in Europe. International Migration Review, 37(4), 965-986.

Domina, T. (2005). Leveling the home advantage: Assessing the effectiveness of parental involvement in elementary school. Sociology of Education, 78(3), 233-249.

Dornbusch, SM. (1989). The sociology of adolescence. Annual Review of Sociology, 15, 233-259.

Dornbusch, SM, Ritter, PL, Leiderman, PH, Roberts, DF, \& Fraleigh, MJ. (1987). The relation of parenting style to adolescent school performance. Child Development, 58, 1244-1257.

Downey, DB. (1995). When bigger is not better: Family size, parental resources, and children's educational performance. American Sociological Review, 60(5), 746-761.

Downey, DB. (2001). Number of siblings and intellectual development: The resource dilution explanation. American Psychologist, 56(6-7), 497.

Faas, C, Benson, MJ, \& Kaestle, CE. (2013). Parent resources during adolescence: effects on education and careers in young adulthood. Journal of Youth Studies, 16(2), 151-171.

Guo, G, \& VanWey, LK. (1999). Sibship size and intellectual development: Is the relationship causal? American Sociological Review, 64(2), 169-187.

Heath, AF, \& Brinbaum, Y. (2007). Explaining ethnic inequalities in educational attainment. Ethnicities, 7(3), 291-306.

Horvat, EMN, Weininger, EB, \& Lareau, A. (2003). From Social Ties to Social Capital: Class Differences in the Relations Between Schools and Parent Networks. American Educational Research Journal, 40(2), 319-351.

Kao, G. (1995). Asian Americans as model minorities? A look at their academic performance. American Journal of Education, 103(2), 121-159.

Kao, G. (2004a). Parental Influences on the Educational Outcomes of Immigrant Youth. International Migration Review, 38(2), 427-449.

Kao, G. (2004b). Social Capital and Its Relevance to Minority and Immigrant Populations. Sociology of Education, 77(4), 172-183.

Kao, G, \& Rutherford, LT. (2007). Does Social Capital Still Matter? Immigrant Minority Disadvantages in School-specific Social Capital and its Effort on Academic Achievement. Sociological Perspectives, 50(1), 27-52.

Karlson, KB, Holm, A, \& Breen, R. (2012). Comparing Regression Coefficients Between Same-sample Nested Models Using Logit and Probit A New Method. Sociological Methodology, 42(1), 286-313.

Keefe, SE, Padilla, AM, \& Carlos, ML. (1979). The Mexican-American extended family as an emotional support system. Human Organization, 38(2), 144-152.

King, G, \& Zeng, L. (2001a). Explaining Rare Events in International Relations. International Organizations, 55(3), 693-715.

King, G, \& Zeng, L. (2001 b). Logistic regression in rare events data. Political Analysis, 9(2), 137-163.

Lauglo, J. (2000). Social Capital Trumping Class and Cultural Capital? Engagement with School among Immigrant Youth. In S Baron, J Field, \& T Schuller (Eds.), Social Capital. Critical Perspectives (pp. 142-167). Oxford: Oxford University Press.

Lieberson, S. (1991). Small N's and Big Conclusions: An Examination of the Reasoning in Comparative Studies Based on a Small Number of Cases. Social Forces, 70(2), 307-320.

Malecki, CK, \& Demaray, MK. (2003). What Type of Support Do They Need? Investigating Student Adjustment as Related to Emotional, Informational, Appraisal, and Instrumental Support. School Psychology Quarterly, 18(3), 231-252.

McNeal, RN. (1999). Parental Involvement as Social Capital: Differential Effectiveness on Science Achievement, Truancy, and Dropping Out. Social Forces, 78(1), 117-144.

Melby, JN, Conger, RD, Fang, S-A, Wickrama, K, \& Conger, KJ. (2008). Adolescent family experiences and educational attainment during early adulthood. Developmental Psychology, 44(6), 1519

Moguérou, L, \& Santelli, E. (2015). The educational supports of parents and siblings in immigrant families. Comparative Migration Studies. doi:10.1186/s40878-015-0012-9.

Moguérou, L, Santelli, E, Primon, J-L, \& Hamel, C. (2013). Taille de la fratrie et statut social des enfants d'immigrés issus de familles nombreuses. Politiques Sociales et Familiales, 111(1), 17-30.

Mood, C. (2010). Logistic regression: Why we cannot do what we think we can do, and what we can do about it. European Sociological Review, 26(1), 67.

Morgan, SL, \& Sørensen, AB. (1999). Parental Networks, Social Closure, and Mathematics Learning: A Test of Coleman's Social Capital Explanation of School Effects. American Sociological Review, 64(5), 661-681.

Nauck, B, \& Kohlmann, A. (1998). Verwandtschaft als soziales Kapital-Netzwerkbeziehungen in türkischen Migrantenfamilien. In M Wagner \& Y Schütze (Eds.), Verwandtschaft. Sozialwissenschaftliche Beiträge zu einem vernachlässigten Thema (pp. 203-235). Stuttgart: Enke Verlag.

OECD. (2005). School factors related to quality and equity. Paris: OECD.

Penn, R, \& Lambert, P. (2009). Children of international migrants in Europe: comparative perspectives. Basingstoke: Palgrave Macmillan.

Pong, S, Hao, L, \& Gardner, E. (2005). The Roles of Parenting Styles and Social Capital in the School Performance of Immigrant Asian and Hispanic Adolescents. Social Science Quarterly, 86(4), 928-950.

Portes, A. (1998). Social Capital: Its Origins and Applications in Modern Sociology. Annual Review of Sociology, 24, 1-24.

Portes, A, \& Fernandez-Kelly, P. (2008). No margin for error: Educational and occupational achievement among disadvantaged children of immigrants. The ANNALS of the American Academy of Political and Social Science, $620(1), 12-36$

Rosenbaum, E, \& Rochford, JA. (2008). Generational patterns in academic performance: The variable effects of attitudes and social capital. Social Science Research, 37(1), 350-372. 
Schnell, P. (2014). Educational mobility of second-generation Turks. Cross-national perspectives. Amsterdam: Amsterdam University Press (IMISCOE Research).

Schnell, P, Keskiner, E, \& Crul, M. (2013). Success against the Odds: Educational pathways of disadvantaged second-generation Turks in France and the Netherlands. Education Inquiry, 4(1), 763-785.

Suárez Orozco, MM. (1991). Migration, minority status, and education: European dilemmas and responses in the 1990s. Anthropology \& Education Quarterly, 22(2), 99-120,

Sun, Y. (1998). The Academic Success of East-Asian-American Students - An Investment Model. Social Science Research, $27(4), 432-456$

Turney, K, \& Kao, G. (2009). Barriers to School Involvement: Are Immigrant Parents Disadvantaged? The Journal of Educational Research, 102(4), 257-271.

Zhou, M. (1997). Growing up American: The Challange Confronting Immigrant Children and Children of Immigrants. Annual Review of Sociology, 23, 63-95.

Zhou, M, \& Bankston, CL. (1998). Growing up American : How Vietnamese children adapt to life in the United States. New York: Russell Sage Foundation.

Submit your manuscript to a SpringerOpen ${ }^{\circ}$ journal and benefit from:

- Convenient online submission

Rigorous peer review

- Immediate publication on acceptance

- Open access: articles freely available online

- High visibility within the field

Retaining the copyright to your article

Submit your next manuscript at $\gg$ springeropen.com 